\title{
A STUDY ON VOCABULARY LEARNING STRATEGIES EMPLOYED BY THE THIRD-YEAR ENGLISH MAJORED STUDENTS AT TRA VINH UNIVERSITY
}

\author{
Trinh Thi Mong Ngoc ${ }^{1}$, Trinh Boi Ngoc ${ }^{2}$
}

\begin{abstract}
Vocabulary is very essential to language learners. If their vocabulary knowledge is insufficient, they will encounter challenges in learning a foreign language. The purpose of this study is to investigate which vocabulary learning strategies were employed most by the third-year English majored students and if genders had an effect on the choice of vocabulary learning strategies. The participants are 40 English majored students at Tra Vinh University including 31 females and 09 males. The questionnaire is the instrument of this research which consists of five different categories: dictionary, guessing, memory, autonomy, and social strategies. The results show that autonomy and dictionary were preferred most by the participants whereas the least popular strategies were guessing and social ones. In addition, genders had no significant impacts on the choice of vocabulary learning strategies.
\end{abstract}

Keywords: English majored students, Tra Vinh University, vocabulary learning strategies.

\section{INTRODUCTION}

Vocabulary plays a crucial role in foreign language acquisition. According to $\mathrm{Na}-$ tion [1], vocabulary is the foundation to develop four language skills: listening, speaking, reading and writing. In addition, McCathy as cited by Astika [2] states that meaningful communication cannot take place without sufficient knowledge of vocabulary.

\footnotetext{
${ }^{1,2}$ English Department, School of Foreign Languages, Tra Vinh University

Email: trinhthimongngoc92@gmail.com

Received date: $29^{t h}$ July 2019; Revised date: $4^{\text {th }}$ September 2019; Accepted date: $12^{\text {th }}$ November 2019
}

Indeed, acquiring vocabulary can help learners to understand what other people say as well as express themselves to others by using words in spoken and written forms. Therefore, if language learners have limited vocabulary, they are unable to use the foreign language effectively.

It is undeniable that improving vocabulary is significantly necessary for language learners in general and English majors at Tra Vinh University in particular. In order to enhance vocabulary build-up, learners need to apply suitable learning strategies. Identifying appropriate vocabulary strategies is even more significant for third-year English majors in order to learn some specialised subjects such as academic writing, translation, interpretation, and research methodology. In some recent years, there have been many researchers conducting surveys on vocabulary learning strategies. In this study, we want to investigate which vocabulary learning strategies are preferred by language learners and how genders affect their choices of those strategies.

The following research questions have been developed to enable the researchers to achieve the objectives of the study:

1 . What are the preferred vocabulary learning strategies used by the third year English majored students at Tra Vinh University?

2. How do genders affect the choice of vocabulary learning strategies of the third year English majored students at Tra Vinh University?

\section{LITERATURE REVIEW}

\section{A. Definitions of learning strategies}

Learning strategies have been defined by some authors as follows: 
Chamot [3] says that learning strategies consist of approaches, techniques and actions taken by students to encourage the learning and acquiring the linguistic information.

According to Rubin [4], learning strategies are those developed by learners and those strategies affect their learning directly while Oxford [5] claims that learning strategies are behaviors used by learners to help their language learning become more successful, self-directed and enjoyable.

\section{B. Classifications of vocabulary learning strategies}

Oxford [6] classifies vocabulary learning strategies into two types: direct and indirect strategies. Direct strategies are memory, cognitive and compensation strategies while indirect strategies include metacognitive, social and affective strategies.

Sharing Oxford's ideas, Schmitt [7] adds the discovery strategies and consolidation strategies. Discovery strategies include determination strategies and social strategies. Consolidation strategies comprise memory strategies, cognitive strategies and metacognitive strategies.

There are some authors giving a detailed explanation for those strategies. According to Schmitt \& McCarthy [8], determination strategies are techniques employed by learners in discovering a new word's meaning without asking another person for help. Kramsch [9] indicates that social strategies show learners' interactions with others for discovering a new word. With these strategies, students can learn and practice vocabulary in groups, then ask teachers to check their work for accuracy. Schmitt [10] emphasizes the role of teachers because they can give the L1 translation to students regarding new words, use synonyms, definitions by paraphrasing or use new words in a sentence, or any combination of these.

Schmitt and McCarthy [8] affirm that memory strategies focus on some previously learned knowledge. This means that learners try to remember words by imagining or grouping words and consolidate them for later use. Oxford [6] suggests that cognitive strategies are techniques assisting learners in linking new information with existing knowledge, as well as analyzing and classifying it. With these strategies, teachers can use word lists, flash cards, notes and labels to help students learn new words. Oxford [6] also explains that metacognitive strategies involve a conscious overview of the learning process. These strategies help learners manage their learning by making decisions, arranging time, concentrating on what they need to learn and self-evaluating their learning.

There have been many researchers investigating the vocabulary learning strategies used by language learners. Dinh [11] surveys five groups of vocabulary learning strategies such as determination, memory, cognitive, metacognitive and social strategies. Le [12] focuses on almost a similar set of strategies with the addition of device-assisted strategies instead of social strategies. Furthermore, Hashemi \& Hadavi [13] mention eight vocabulary learning strategies including dictionary, guessing, study preferences, memory, autonomy, note-taking, selective attention, and social strategies. In the same vein, Manuel [14] and Aravind \& Rajasekaran [15] investigate the same strategies: determination, memory, cognitive, metacognitive, and social strategies. Similarly, Astika [2] surveys only four strategies: cognitive, metacognitive, memory, and determination strategies.

In this current study, the five following strategies such as dictionaries, guessing, memory, autonomy and social strategies are thoroughly justified. Firstly, Carter [16] suggests that dictionaries provide students with detailed guidance related pronunciation, grammar and usage with explanations. They also give examples of words used in different contexts. In addition, according to Oxford [6], guessing strategies can be made by relying on a wide range of clues including linguistic and nonlinguistic ones. In terms of linguistic clues, learners apply their semantic or syntactic knowledge while for nonlinguistic clues, they use their topical knowledge to 
decode the meaning of new words.

According to Oxford as cited by Benkhenafou [17], memory refers to the strategies through which the learners use some imagery or groupings in order to help the learners associate a new word with things already familiar to them. Regarding autonomy, Holec [18] claims that autonomy is "the ability to take charge of one's own learning" (p. 3).

Schmitt [10] states that social strategies involve learners' interaction with other people to explore the meaning of words.

The five strategies above were surveyed in order to find the preferred strategies employed by third-year English majors and if genders affect their choice of vocabulary learning strategies.

\section{Related studies}

With regard to vocabulary learning strategies, Dinh [11] identifies the vocabulary learning strategies commonly used by the students at Hung Vuong Gifted High School and the differences in vocabulary learning strategies by genders. The data showed that most of the strategies were not used with high frequency. The participants used determination strategies more frequently than memory, cognitive, metacognitive and social strategies. Similarly, Astika [2] examines the vocabulary learning strategies used by students when they learned new words and finds out that determination strategies are employed more than others.

However, Hashemi \& Hadavi [13] explore the use and preferences of vocabulary learning strategies among the students in an Iranian university. The findings revealed that social and guessing strategies obtained the highest mean scores whereas note-taking and autonomy were the least used strategies.

Le [12] investigates the vocabulary learning strategies preferred by university students. The results show that device-assisted strategies occupy the highest mean score while metacognitive strategies show the lowest mean score. Whereas, Aravind \& Ra- jasekaran [15] discover that cognitive strategies were the most popularly used by research scholars at VIT Chennai, Tamil, Nadu, followed by determination strategies. Metacognitive strategies were the third most frequently used while memory and social strategies were the least popular.

Concerning the effect of genders on the choice of vocabulary learning strategies, Dinh [11] finds out that the difference between males and females in the use of vocabulary learning strategies was not significant. Likewise, Omaar [19] indicates that genders had no effect on students' choice of vocabulary learning strategies. By contrast, Hashemi \& Hadavi [13] reveal that female students prefered social strategies while male students were in favor of autonomy and note-taking strategies.

\section{METHODOLOGY}

\section{A. Research design}

The descriptive survey method was used to investigate the vocabulary learning strategies used by the third-year English majors and the effect of genders on their choice of vocabulary learning strategies.

\section{B. Participants of the study}

Forty out of sixty-seven third-year English majored students of Tra Vinh University were included in this study, including 31 females and 09 males. The significant difference in the numbers of males and females is due to the dominance of female students over male students in English language learning.

\section{Instrument}

The research instrument employed to collect data for this study was the questionnaire adapted from Hashemi \& Hadavi's questionnaire [13]. The questionnaire covered five different categories including Dictionary strategies (items 1-7), Guessing strategies (items 8-10), Memory strategies (items 1119), Autonomy strategies (items 20-23), Social strategies (items 24-27). The statements were designed by using a five-point Likertscale, ranging from never to always. 


\section{Procedures}

The questionnaire was designed and distributed to the participants who were asked to complete the questionnaire anonymously in their break time. The data collected from the questionnaire was analyzed by using the software SPSS (Statistic Package for the Social Sciences) version 22.

\section{RESULTS AND DISCUSSION}

\section{A. The reliability of the questionnaire}

Table 1: Reliability Statistics of the questionnaire

Reliability Statistics

\begin{tabular}{|c|c|}
\hline Cronbach's Alpha & N of Items \\
\hline .85 & 27 \\
\hline
\end{tabular}

A group of 40 students completed the questionnaires. All the data collected from the questionnaire were computed to check the frequency and internal reliability coefficient. The results in Table 1 showed that the questionnaire used in this research was reliable with Cronbach Alpha's coefficient of .85 for 27 statements in total.

\section{B. The preferred vocabulary learning strate-} gies employed by participants

Table 2: Descriptive Statistics of five groups of vocabulary learning strategies

\begin{tabular}{|c|c|c|c|c|c|c|c|c|}
\hline & \multirow[b]{2}{*}{$\mathrm{N}$} & \multirow[b]{2}{*}{ Mean } & \multirow[b]{2}{*}{$\begin{array}{c}\text { Std. } \\
\text { Deviation }\end{array}$} & \multirow[b]{2}{*}{$\begin{array}{l}\text { Std. } \\
\text { Error }\end{array}$} & \multicolumn{2}{|c|}{$\begin{array}{l}95 \% \text { Confidence } \\
\text { Interval for } \\
\text { Mean }\end{array}$} & \multirow[b]{2}{*}{ Minimum } & \multirow[b]{2}{*}{ Maximum } \\
\hline & & & & & $\begin{array}{l}\text { Lower } \\
\text { Bound }\end{array}$ & $\begin{array}{l}\text { Upper } \\
\text { Bound }\end{array}$ & & \\
\hline Dictionary mean & 40 & 3.74 & .64 & .10 & 3.53 & 3.94 & 2.00 & 4.86 \\
\hline Guessing mean & 40 & 3.23 & .51 & .08 & 3.07 & 3.40 & 2.33 & 4.33 \\
\hline Memory mean & 40 & 3.41 & .53 & .08 & 3.24 & 3.58 & 2.00 & 4.44 \\
\hline Autonomy mean & 40 & 3.83 & .73 & .12 & 3.60 & 4.06 & 2.00 & 5.00 \\
\hline Social mean & 40 & 3.29 & .65 & .10 & 3.09 & 3.50 & 2.00 & 4.50 \\
\hline Total & $\begin{array}{c}20 \\
0\end{array}$ & 3.50 & .66 & .046 & 3.41 & 3.59 & 2.00 & 5.00 \\
\hline
\end{tabular}

Table 2 indicates the mean score for "Autonomy" $(\mathrm{M}=3.83, \mathrm{SD}=0.73)$, higher than the mean scores of the four other groups of vocabulary learning strategies:
"Dictionary" (M=3.74, SD=0.64), "Memory" $(\mathrm{M}=3.41, \mathrm{SD}=0.53)$, "Social strategies" $(\mathrm{M}=3.29, \mathrm{SD}=0.65)$ and "Guessing" $(\mathrm{M}=3.23, \mathrm{SD}=0.51)$.

Table 3: Differences between strategies

\begin{tabular}{|c|c|c|c|c|c|}
\hline & Sum of Squares & df & Mean Square & F & Sig. \\
\hline Between Groups & 11,47 & 4 & 2.87 & 7.56 & .00 \\
\hline Within Groups & 74.00 & 195 & .38 & & \\
\hline Total & 85.47 & 199 & & & \\
\hline
\end{tabular}

Table 4: Multiple Comparisons

\begin{tabular}{|c|c|c|c|c|c|c|}
\hline \multicolumn{7}{|c|}{ Tukey HSD } \\
\hline \multirow{2}{*}{ (I) total mean } & \multirow{2}{*}{ (J) total mean } & \multirow{2}{*}{ Mean Difference (1-J) } & \multirow{2}{*}{ Sud. Error } & \multirow{2}{*}{ Sig. } & \multicolumn{2}{|c|}{$95 \%$ Confidence Interval } \\
\hline & & & & & Lower Bound & Uppet Bound \\
\hline \multirow{4}{*}{ Dictionary mean } & Guessing mean & $.50^{*}$ & .14 & .00 & .12 & .88 \\
\hline & Memory mean & 32 & .14 & .13 & .05 & .70 \\
\hline & Autonomy mean & .10 & .14 & .96 & -.47 & .28 \\
\hline & Social mean & $.44^{*}$ & .14 & .01 & .06 & .82 \\
\hline \multirow{4}{*}{ Guessing mean } & Dictionary mean & $-50^{*}$ & .14 & .00 & .88 & .12 \\
\hline & Memory mean & .18 & .14 & .70 & .56 & .20 \\
\hline & Autonomy mean & $-.60^{*}$ & .14 & .00 & -.98 & .22 \\
\hline & Social mean & -.06 & .14 & .99 & .44 & .32 \\
\hline \multirow{4}{*}{ Memory mean } & Dictionary mean & .32 & .14 & .13 & -.70 & .05 \\
\hline & Guessing mean & .18 & .14 & .70 & .20 & .56 \\
\hline & Autonomy mean & $-42^{*}$ & .14 & .02 & -.80 & -.04 \\
\hline & Social mean & .12 & .14 & .91 & .26 & 50 \\
\hline \multirow{4}{*}{ Autonomy mean } & Dictionary mean & .10 & .14 & .96 & .28 & 47 \\
\hline & Guessing mean & $.60^{*}$ & .14 & .00 & .22 & .98 \\
\hline & Memory mean & $.42^{*}$ & .14 & .02 & .04 & .80 \\
\hline & Social mean & $.54^{*}$ & .14 & .00 & .16 & .92 \\
\hline \multirow{4}{*}{ Social mean } & Dictionary mean & $.44^{*}$ & .14 & .013 & .82 & .06 \\
\hline & Guessing mean & .06 & .14 & .99 & -32 & .44 \\
\hline & Memory mean & .12 & .14 & .91 & -50 & .26 \\
\hline & Autonomy mean & $.54^{*}$ & .14 & .00 & .92 & .16 \\
\hline
\end{tabular}

As shown in Table 4, Post hoc comparisons using the Tukey HSD test indicated that the mean score for "Autonomy" $(\mathrm{M}=3.83$, $\mathrm{SD}=0.73$ ) was significantly higher than the mean scores of "Guessing", $\mathrm{p}=0.00$; "Memory", $\mathrm{p}=0.02$ and "Social strategies", $\mathrm{p}=0.00$. However, the mean score for "Autonomy" was insignificantly higher than the mean score of "Dictionary", $\mathrm{p}=0.96$.

Table 4 shows that "Autonomy" and "Dictionary" are the most popular groups of strategies employed by the participants while "Social strategies" and "Guessing" are the least used strategies. The results of this study are different from those found in Hashemi \& Hadavi's study [13]. In their study, social strategies and guessing strategies had the highest obtained scores whereas dictionary strategies obtained the moderate use 
and autonomy strategies had the lowest mean scores.

C. The impact of genders on the choice of vocabulary learning strategies of English learners

Table 5: Group Statistics of genders towards dictionary strategies

\begin{tabular}{|c|c|c|c|c|c|}
\hline & Gender & $\mathrm{N}$ & Mean & $\begin{array}{c}\text { Std. } \\
\text { Deviation }\end{array}$ & $\begin{array}{c}\text { Std. Error } \\
\text { Mean }\end{array}$ \\
\hline \multirow{2}{*}{ Dictionary mean } & male & 9 & 3.67 & .75 & .25 \\
\cline { 2 - 6 } & female & 31 & 3.76 & .62 & .11 \\
\hline
\end{tabular}

Table 6: Independent Samples Test of genders towards dictionary strategies

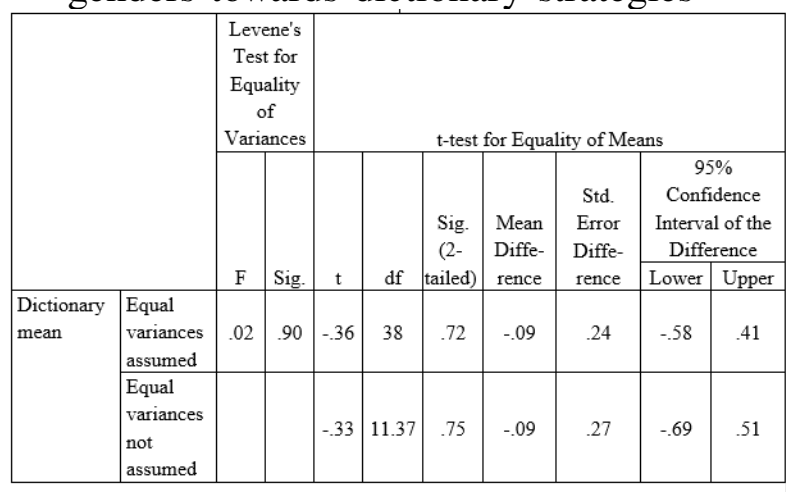

The results from Table 5 show that the mean score of female students $(M=3.76)$ is higher than that of male students $(\mathrm{M}=3.67)$. Then, an independent-sample t-test was conducted to compare the effect of genders on the use of dictionary strategies. However, the result in Table 6 indicates that there are no significant differences in the mean scores for female students $(\mathrm{M}=3.76, \mathrm{SD}=0.62)$ and male students $(\mathrm{M}=3.67, \mathrm{SD}=0.75) ; \mathrm{t}(38)=-0.36$, $\mathrm{p}=0.72$. These results suggest that genders did not really have an effect on the choice of dictionary strategies.

Table 7: Group Statistics of genders towards guessing strategies

\begin{tabular}{|c|c|c|c|c|c|}
\hline & Gender & $\mathrm{N}$ & Mean & Std. Deviation & Std. Error Mean \\
\hline \multirow{2}{*}{ Guessing mean } & male & 9 & 3.04 & .48 & .16 \\
\cline { 2 - 6 } & female & 31 & 3.29 & .51 & .09 \\
\hline
\end{tabular}

Table 8: Independent Samples Test of genders towards guessing strategies

\begin{tabular}{|c|c|c|c|c|c|c|c|c|c|c|}
\hline & \multicolumn{2}{|c|}{$\begin{array}{c}\text { Levene's } \\
\text { Test for } \\
\text { Equality } \\
\quad \text { of } \\
\text { Variances }\end{array}$} & \multicolumn{7}{|c|}{ t-test for Equality of Means } \\
\hline & & \multirow[b]{2}{*}{$\mathrm{F}$} & \multirow[b]{2}{*}{ Sig. } & \multirow[b]{2}{*}{$t$} & \multirow[b]{2}{*}{$\mathrm{df}$} & \multirow{2}{*}{$\begin{array}{c}\text { Sig. } \\
(2- \\
\text { tailed })\end{array}$} & \multirow{2}{*}{$\begin{array}{c}\text { Mean } \\
\text { Difference }\end{array}$} & \multirow{2}{*}{$\begin{array}{l}\text { Std. Error } \\
\text { Difference }\end{array}$} & \multicolumn{2}{|c|}{\begin{tabular}{|c}
$95 \%$ \\
Confidence \\
Interval of the \\
Difference \\
\end{tabular}} \\
\hline & & & & & & & & & Lower & Upper \\
\hline \multirow[t]{2}{*}{$\begin{array}{c}\text { Guessing } \\
\text { mean }\end{array}$} & $\begin{array}{c}\text { Equal } \\
\text { variances } \\
\text { assumed }\end{array}$ & .03 & .88 & -1.33 & 38 & .19 & -.25 & .19 & -.64 & .13 \\
\hline & $\begin{array}{c}\text { Equal } \\
\text { variances } \\
\text { not } \\
\text { assumed } \\
\end{array}$ & & & -1.37 & 13.54 & .19 & -.25 & .19 & -.65 & .15 \\
\hline
\end{tabular}

It is clear from Table 7 that the mean score of female students $(\mathrm{M}=3.29)$ is higher than that of male students $(M=3.04)$. Then, an independent-sample t-test was conducted to compare the effect of genders on the use of guessing strategies. However, the result in Table 8 indicates that there are no significant differences in the mean scores for female students $(\mathrm{M}=3.29, \mathrm{SD}=0.51)$ and male students $(\mathrm{M}=3.04, \mathrm{SD}=0.48) ; \mathrm{t}(38)=-1.33, \mathrm{p}=0.19$. These results suggested that genders did not affect the choice of guessing strategies.

Table 9: Group Statistics of genders towards memory strategies

\begin{tabular}{|c|c|c|c|c|c|}
\hline & Gender & $\mathrm{N}$ & Mean & $\begin{array}{c}\text { Std. } \\
\text { Deviation }\end{array}$ & $\begin{array}{c}\text { Std. Error } \\
\text { Mean }\end{array}$ \\
\hline Memory mean & male & 9 & 3.26 & .70 & .23 \\
\cline { 2 - 6 } & female & 31 & 3.46 & .47 & .08 \\
\hline
\end{tabular}

Table 10: Independent Samples Test of genders towards memory strategies

\begin{tabular}{|c|c|c|c|c|c|c|c|c|c|c|}
\hline & \multicolumn{2}{|c|}{$\begin{array}{l}\text { Levene's } \\
\text { Test for } \\
\text { Equality of } \\
\text { Variances }\end{array}$} & \multicolumn{7}{|c|}{ t-test for Equality of Means } \\
\hline & & \multirow[b]{2}{*}{ F } & \multirow[b]{2}{*}{ Sig. } & \multirow[b]{2}{*}{$\mathrm{t}$} & \multirow[b]{2}{*}{ Df } & \multirow{2}{*}{$\begin{array}{c}\text { Sig. } \\
(2- \\
\text { tailed) }\end{array}$} & \multirow{2}{*}{$\begin{array}{l}\text { Mean } \\
\text { Diffe- } \\
\text { rence }\end{array}$} & \multirow[t]{2}{*}{$\begin{array}{l}\text { Std. } \\
\text { Error } \\
\text { Diffe- } \\
\text { rence }\end{array}$} & \multicolumn{2}{|c|}{$\begin{array}{c}95 \% \\
\text { Confidence } \\
\text { Interval of the } \\
\text { Difference }\end{array}$} \\
\hline & & & & & & & & & Lower & Upper \\
\hline \multirow[t]{2}{*}{$\begin{array}{l}\text { Memory } \\
\text { mean }\end{array}$} & \begin{tabular}{|l} 
Equal \\
variances \\
assumed
\end{tabular} & .47 & .50 & -.98 & 38 & .33 & -.20 & .20 & -.60 & .21 \\
\hline & \begin{tabular}{|l|} 
Equal \\
variances \\
not \\
assumed
\end{tabular} & & & -.79 & 10.21 & .45 & -.20 & .25 & -.74 & .35 \\
\hline
\end{tabular}

The data from Table 9 indicates that the mean score of female students $(\mathrm{M}=3.46)$ is 
higher than that of male students $(\mathrm{M}=3.26)$. Then, an independent-sample t-test was conducted to compare the effect of genders on the use of memory strategies. However, the result in Table 10 indicates that there were no significant differences in the mean scores for female students $(\mathrm{M}=3.46, \mathrm{SD}=0.47)$ and male students $(\mathrm{M}=3.26, \mathrm{SD}=0.70) ; \mathrm{t}(38)=$ $0.98, \mathrm{p}=0.33$. These results suggest that genders did not influence the choice of memory strategies.

Table 11: Group Statistics of genders towards social strategies

\begin{tabular}{|c|c|c|c|c|c|}
\hline & Gender & $\mathrm{N}$ & Mean & $\begin{array}{c}\text { Std. } \\
\text { Deviation }\end{array}$ & $\begin{array}{c}\text { Std. Error } \\
\text { Mean }\end{array}$ \\
\hline \multirow{2}{*}{$\begin{array}{c}\text { Social } \\
\text { mean }\end{array}$} & male & 9 & 3.08 & .81 & .27 \\
\cline { 2 - 6 } & female & 31 & 3.35 & .60 & .11 \\
\hline
\end{tabular}

Table 12: Independent Samples Test of genders towards social strategies

\begin{tabular}{|c|c|c|c|c|c|c|c|c|c|c|}
\hline & \multicolumn{2}{|c|}{$\begin{array}{l}\text { Levene's } \\
\text { Test for } \\
\text { Equality of } \\
\text { Variances }\end{array}$} & \multicolumn{7}{|c|}{ t-test for Equality of Means } \\
\hline & & \multirow[b]{2}{*}{$\mathrm{F}$} & \multirow[b]{2}{*}{ Sig. } & \multirow[b]{2}{*}{$\mathrm{t}$} & \multirow[b]{2}{*}{ Df } & \multirow{2}{*}{$\begin{array}{l}\text { Sig. } \\
(2- \\
\text { tailed })\end{array}$} & \multirow{2}{*}{$\begin{array}{l}\text { Mean } \\
\text { Diffe- } \\
\text { rence }\end{array}$} & \multirow{2}{*}{$\begin{array}{c}\text { Std. } \\
\text { Error } \\
\text { Diffe- } \\
\text { rence }\end{array}$} & \multicolumn{2}{|c|}{$\begin{array}{c}95 \% \\
\text { Confidence } \\
\text { Interval of the } \\
\text { Difference } \\
\end{array}$} \\
\hline & & & & & & & & & Lower & Upper \\
\hline \multirow[t]{2}{*}{$\begin{array}{l}\text { Social } \\
\text { mean }\end{array}$} & $\begin{array}{c}\text { Equal } \\
\text { variances } \\
\text { assumed }\end{array}$ & 2.24 & .14 & -1.10 & 38 & .28 & -.27 & .25 & -.77 & .23 \\
\hline & $\begin{array}{c}\text { Equal } \\
\text { variances } \\
\text { not } \\
\text { assumed }\end{array}$ & & & -.93 & 10.70 & .37 & -.27 & .29 & -.91 & .37 \\
\hline
\end{tabular}

Table 11 reveals that the mean score of female students $(M=3.35)$ was higher than that of male students $(\mathrm{M}=3.08)$. Then, an independent-sample t-test was conducted to compare the effect of genders on the use of social strategies. However, the result in Table 12 indicates that there was no significant difference in the mean scores for female students $(\mathrm{M}=3.35, \mathrm{SD}=0.60)$ and male students $(\mathrm{M}=3.08, \mathrm{SD}=0.81) ; \mathrm{t}(38)=-1.10, \mathrm{p}=0.28$. These results suggested that genders did not influence the choice of social strategies.

Table 13 presents that the mean score of female students $(\mathrm{M}=3.94)$ was higher than that of male students $(\mathrm{M}=3.44)$. Then, an independent-sample t-test was conducted to
Table 13: Group Statistics of genders towards autonomy strategies

\begin{tabular}{|c|c|c|c|c|c|}
\hline & Gender & N & Mean & $\begin{array}{c}\text { Std. } \\
\text { Deviation }\end{array}$ & $\begin{array}{c}\text { Std. Error } \\
\text { Mean }\end{array}$ \\
\hline Autonomy mean & Male & 9 & 3.44 & .89 & .30 \\
\cline { 2 - 6 } & Female & 31 & 3.94 & .65 & .12 \\
\hline
\end{tabular}

Table 14: Independent Samples Test of genders towards autonomy strategies

\begin{tabular}{|c|c|c|c|c|c|c|c|c|c|c|}
\hline & \multicolumn{2}{|c|}{\begin{tabular}{|c|} 
Levene's \\
Test for \\
Equality \\
of \\
Variances \\
\end{tabular}} & \multicolumn{7}{|c|}{ t-test for Equality of Means } \\
\hline & & \multirow[b]{2}{*}{$\mathrm{F}$} & \multirow[b]{2}{*}{ Sig. } & \multirow[b]{2}{*}{$\mathrm{T}$} & \multirow[b]{2}{*}{ Df } & \multirow{2}{*}{\begin{tabular}{|c} 
Sig. \\
$(2-$ \\
tailed $)$
\end{tabular}} & \multirow{2}{*}{$\begin{array}{l}\text { Mean } \\
\text { Diffe- } \\
\text { rence }\end{array}$} & \multirow{2}{*}{$\begin{array}{c}\text { Std. } \\
\text { Error } \\
\text { Diffe- } \\
\text { rence }\end{array}$} & \multicolumn{2}{|c|}{$\begin{array}{c}95 \% \\
\text { Confidence } \\
\text { Interval of the } \\
\text { Difference }\end{array}$} \\
\hline & & & & & & & & & Lower & Upper \\
\hline \multirow[t]{2}{*}{ Autonomymean } & \begin{tabular}{|l} 
Equal \\
variances \\
assumed
\end{tabular} & .91 & .35 & -1.87 & 38 & .07 & -.50 & .27 & -1.04 & .042 \\
\hline & \begin{tabular}{|l|} 
Equal \\
variances \\
not assumed
\end{tabular} & & & -1.57 & 10.58 & .15 & -.50 & .32 & -1.20 & .21 \\
\hline
\end{tabular}

compare the effect of genders on the use of autonomy strategies. However, the result in Table 14 indicates that there was no significant difference in the mean scores for female students $(\mathrm{M}=3.94, \mathrm{SD}=0.65)$ and male students $(\mathrm{M}=3.44, \mathrm{SD}=0.89) ; \mathrm{t}(38)=-1.87$, $\mathrm{p}=0.70$. These results suggested that genders did not influence the choice of social strategies.

It was concluded that genders had no effects on the use of vocabulary learning strategies. By comparison, Hashemi \& Hadavi [13] find that female students used social strategies more while male students preferred autonomy strategies. However, the results of this study were in line with the study results conducted by Dinh [11] and Manuel [14] who conclude that there was no statistically significant difference in the use of vocabulary learning strategies and between genders.

\section{CONCLUSION AND RECOMMENDATIONS}

This present study aimed to identify the use of vocabulary learning strategies by English learners at Tra Vinh University. The results indicated that autonomy and dictionary were the most popular strategies amongst the participants while social and guessing 
strategies were the least popular ones. In terms of the effects of genders on the use of vocabulary learning strategies, it was found that genders had no impact on the choice of vocabulary learning strategies. The findings if this study will contribute to enhancing the awareness of the importance of vocabulary learning strategies in language learning and teaching. Thereby, teachers will diversify their teaching methods by introducing these vocabulary learning strategies and techniques to their students. For students, they are enabled to get access to a variety of vocabulary learning strategies to broaden their vocabulary sources.

\section{REFERENCES}

[1] Nation I S. Learning vocabulary in another language. Ernst Klett Sprachen; 2001.

[2] Astika I G. Vocabulary learning strategies of secondary school students. IJOLTL: Indonesian Journal of Language Teaching and Linguistics. 2016;1(1):18.

[3] Chamot A U. Language learning strategy instruction: Current issues and research. Annual review of applied linguistics. 2005;25:112-30.

[4] Rubin J. Learner strategies: Theoretical assumptions, research history and typology. Learner strategies in language learning. 1987;p. 15-30.

[5] Oxford R, Nyikos M. Variables affecting choice of language learning strategies by university students. The modern language journal. 1989;73(3):291-300.

[6] Oxford R. Language learning strategies: What every teacher should know. Boston: Newbury House; 1990.

[7] Schmitt N. Vocabulary: Description, Acquisition and Pedagogy. In: Schmitt N, McCarthy M, editors. Vocabulary learning strategies. Cambridge University Press; 1997. p. 199-227.

[8] Schmitt N, McCarthy M. Vocabulary: Description, acquisition and pedagogy. Cambridge University Press; 1997.

[9] Kramsch CJ. Word watching: Learning vocabulary becomes a hobby. Foreign Language Annals. 1979;12(2):153-8.

[10] Schmitt N. Vocabulary in language teaching. Ernst Klett Sprachen; 2000.

[11] Đinh Thụy Hằng. Vocabulary learning strategies employed by students at Hung Vuong Gifted High School. ULIS; 2008.

[12] Lê Phạm Hoài Hương. A survey study on academic vocabulary learning strategies by EFL university students. Journal of Language Teaching and Research. 2018;9(5):1009-1016.
[13] Hashemi Z, Hadavi M. Investigation of vocabulary learning strategies among EFL Iranian medical sciences students. Procedia-Social and Behavioral Sciences. 2015;192:629-37.

[14] Manuel N N. Evaluating Vocabulary Learning Strategies (VLS): Gender differences, the most and least used (VLS) among Angolan EFL Students at the Faculty of Arts (Luanda, Angola). International Journal of Scientific Research in Education. 2017;10(5):483504.

[15] Aravind B R. Rajasekaran V. A study on vocabulary learning strategies of research scholars. International Journal of Research in Teacher Education. 2018;9(2):16-25.

[16] Carter R. Vocabulary and second/foreign language teaching. Language Teaching. 1987;20(1):3-16.

[17] Benkhenafou HH. Memory strategies: boosting vocabulary learning and learner autonomy. International Journal of English and Literature. 2015;5(4):113-22.

[18] Holec H. Autonomy and foreign language learning. Oxford: Pergamon Press; 1979.

[19] Omaar AO. EFL Vocabulary Learning Strategies among Tuareg People. Doctoral dissertation, Washington State University; 2016. 